San Jose State University

SJSU ScholarWorks

Mineta Transportation Institute Publications

$6-2020$

\title{
Southern California Regional Transit Training Consortium: Skills Gap \& Needs Assessment
}

Tyler Reeb

California State University, Long Beach

Benjamin Olson

California State University, Long Beach

Follow this and additional works at: https://scholarworks.sjsu.edu/mti_publications

Part of the Transportation Engineering Commons

\section{Recommended Citation}

Tyler Reeb and Benjamin Olson. "Southern California Regional Transit Training Consortium: Skills Gap \& Needs Assessment" Mineta Transportation Institute Publications (2020). https://doi.org/10.31979/ mti.2020.1932

This Report is brought to you for free and open access by SJSU ScholarWorks. It has been accepted for inclusion in Mineta Transportation Institute Publications by an authorized administrator of SJSU ScholarWorks. For more information, please contact scholarworks@sjsu.edu. 
SJSU San os sispie

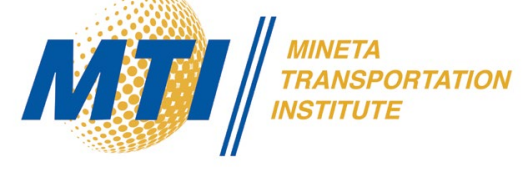

Southern California Regional Transit Training Consortium: Skills Gap \& Needs Assessment

Tyler Reeb, PhD

Ben Olson

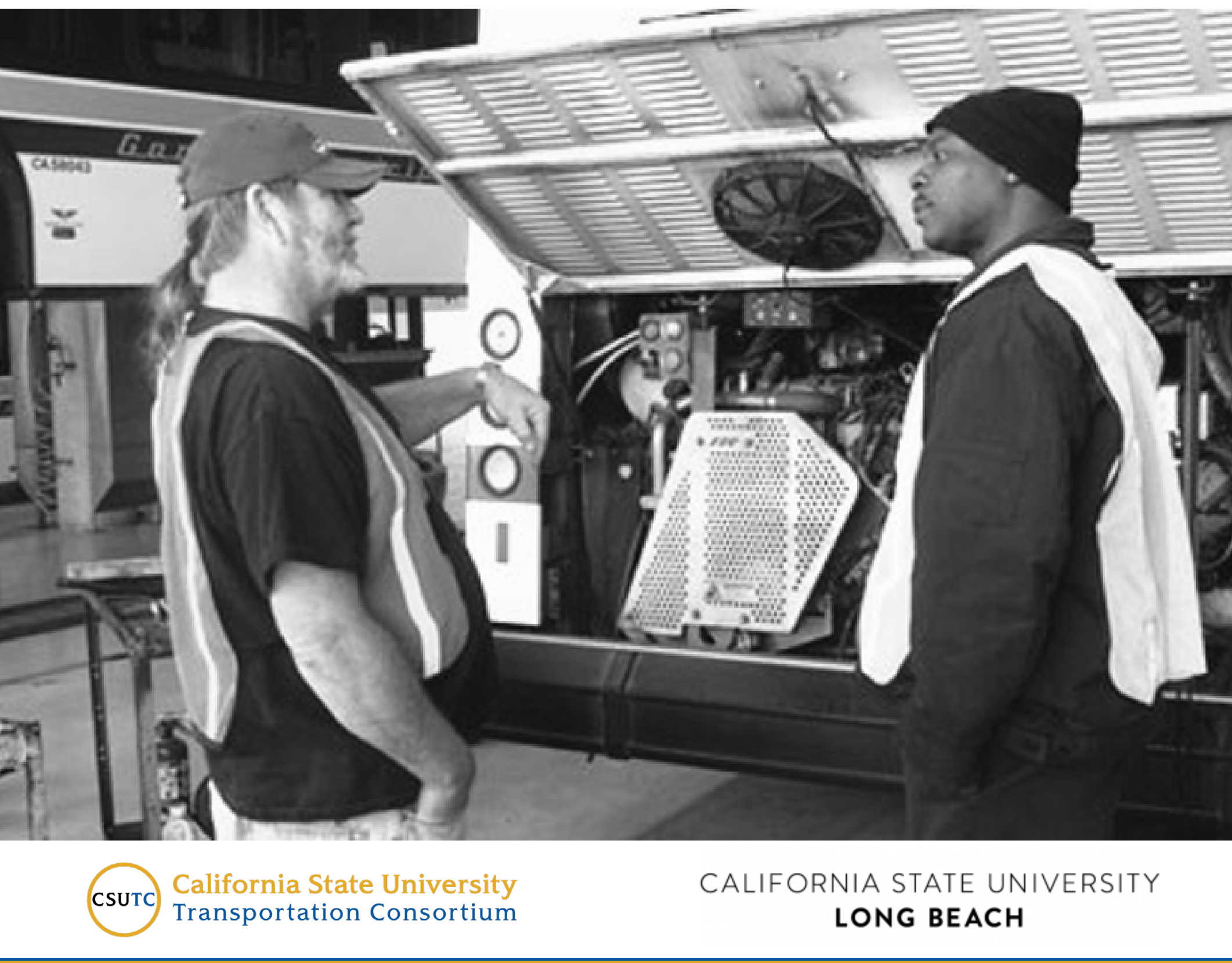




\section{MINETA TRANSPORTATION INSTITUTE}

Founded in 199I, the Mineta Transportation Institute (MTI), an organized research and training unit in partnership with the Lucas College and Graduate School of Business at San José State University (SJSU), increases mobility for all by improving the safety, efficiency, accessibility, and convenience of our nation's transportation system. Through research, education, workforce development, and technology transfer, we help create a connected world. MTI leads the four-university. MTI leads the four-university California State University Transportation Consortium funded by the State of California through Senate Bill I.

MTl's transportation policy work is centered on three primary responsibilities:

\section{Research}

MTI works to provide policy-oriented research for all levels of government and the private sector to foster the development of optimum surface transportation systems. Research areas include: bicycle and pedestrian issues; financing public and private sector transportation improvements; intermodal connectivity and integration; safety and security of transportation systems; sustainability of transportation systems; transportation / land use / environment; and transportation planning and policy development. Certified Research Associates conduct the research. Certification requires an advanced degree, generally a Ph.D., a record of academic publications, and professional references. Research projects culminate in a peer-reviewed publication, available on TransWeb, the MTI website (http://transweb.sjsu.edu).

\section{Education}

The Institute supports education programs for students seeking a career in the development and operation of surface transportation systems. MTI, through San José State University, offers an AACSBaccredited Master of Science in Transportation Management and graduate certificates in Transportation Management, Transportation Security, and High-Speed Rail Management that serve to prepare the nation's transportation managers for the 2 I st century. With the active assistance of the California Department ofTransportation (Caltrans), MTI delivers its classes over a state-of-the-art videoconference network throughout the state of California and via webcasting beyond, allowing working transportation professionals to pursue an advanced degree regardless of their location. To meet the needs of employers seeking a diverse workforce, MTl's education program promotes enrollment to under-represented groups.

\section{Information and Technology Transfer}

MTI utilizes a diverse array of dissemination methods and media to ensure research results reach those responsible for managing change. These methods include publication, seminars, workshops, websites, social media, webinars, and other technology transfer mechanisms. Additionally, MTI promotes the availability of completed research to professional organizations and journals and works to integrate the research findings into the graduate education program. MTl's extensive collection of transportation- related publications is integrated into San José State University's world-class Martin Luther King, Jr. Library.

\section{Disclaimer}

The contents of this report reflect the views of the authors, who are responsible for the facts and accuracy of the information presented herein. This document is disseminated in the interest of information exchange. The report is funded, partially or entirely, by a grant from the State of California. This report does not necessarily reflect the official views or policies of the State of California or the Mineta Transportation Institute, who assume no liability for the contents or use thereof. This report does not constitute a standard specification, design standard, or regulation. 
REPORT 20-22

\title{
SOUTHERN CALIFORNIA REGIONAL TRANSIT TRAINING CONSORTIUM: SKILLS GAP AND NEEDS ASSESSMENT
}

\author{
Tyler Reeb, PhD \\ Ben Olson
}

June 2020

A publication of

Mineta Transportation Institute

Created by Congress in 1991

College of Business

San José State University

San José, CA 95192-0219 


\section{TECHNICAL REPORT DOCUMENTATION PAGE}

1. Report No. 20-22

4. Title and Subtitle

Southern California Regional Transit Training Consortium: Skills Gap \&

Needs Assessment

7. Authors

Tyler Reeb, PhD, https://orcid.org/0000-0002-8056-9939

Ben Olson, https://orcid.org/0000-0002-2991-4020
3. Recipient's Catalog No.

5. Report Date

June 2020

6. Performing Organization Code

8. Performing Organization Report CA-MTI-1932

9. Performing Organization Name and Address

Mineta Transportation Institute

College of Business

San José State University

San José, CA 95192-0219

12. Sponsoring Agency Name and Address

State of California SB1 2017/2018

Trustees of the California State

University

Sponsored Programs Administration

401 Golden Shore, 5th Floor

Long Beach, CA 90802

\section{Supplemental Notes}

DOI: $10.31979 / \mathrm{mti} .2020 .1932$

\section{Abstract}

The transit sector grows and evolves quickly with the needs of growing, busy cities. With this growth comes a need for more transit workers and more training to ensure workers can best serve their diverse communities. This report contains a transit training needs assessment and gap analysis to identify the most pressing challenges of the evolving transit workforce served by the Southern California Regional Transit Training Consortium (SCRTTC). Most importantly, this report documents and determines SCRTTC priorities to ensure the incumbent and future transit workforce is equipped with the professional and technological skills required to address the transformational trends affecting the transit sector. The report primarily utilized qualitative methods with the use of a series of interviews, a focus group, a workshop, and an online survey. Above all, this assessment discovered that existing SCRTTC training curriculum is respected, and there is strong demand for additional topics. Transit maintenance professionals consistently endorsed the value and quality of SCRTTC training-they just want more of it. They want it to be developed more efficiently and at a higher volume. They seek more localized and customized delivery methods for training and curriculum. All of those findings compel a question: How can SCRTTC make organizational changes to more rapidly develop curriculum and provide targeted training programs for technicians? This report recommends SCRTTC integrate a suite of digital products into the SCRTTC website to respond to the needs documented in this assessment-namely higher capacity for more training offerings and more online delivery methods while simultaneously enhancing member demands for more customized and location-based training. Implementing the digital platform recommended in this report would empower SCRTTC leadership to foster increased interactivity between transit agencies, training partners, and SCRTTC management. These digital tools would enable SCRTTC to expand its coverage to all of California. This statewide approach to transit training could be used to implement similar consortia in states throughout the U.S.

\section{Key Words}

Public transit, Electric buses, Maintenance, Fuel cell vehicles, Education and training

19. Security Classif. (of this report) Unclassified

\section{Distribution Statement}

No restrictions. This document is available to the public through

The National Technical Information Service, Springfield, VA 22161
20. Security Classif. (of this page) Unclassified

\section{No. of Pages \\ 31}

22. Price 


\title{
Copyright $\odot 2020$ \\ by Mineta Transportation Institute \\ All rights reserved
}

DOI: 10.31979/mti.2020.1932

\author{
Mineta Transportation Institute \\ College of Business \\ San José State University \\ San José, CA 95192-0219 \\ Tel: (408) 924-7560 \\ Fax: (408) 924-7565 \\ Email: mineta-institute@sjsu.edu
}

transweb.sjsu.edu 


\section{ACKNOWLEDGMENTS}

The authors wish to acknowledge the support of the Southern California Regional Transit Training Consortium membership, the American Public Transportation Association, and the College of Professional and International Education at California State University, Long Beach, which houses the Center for International Trade and Transportation. Funding for this research was provided by the State of California SB1 2017/2018 through the Trustees of the California State University (Agreement \# ZSB12017-SJAUX) and the California State University Transportation Consortium. The authors thank Editing Press, for editorial services, Megan Orr and Brittany Cooper who served as research assistants on this project, as well as MTI staff, including Executive Director Karen Philbrick, PhD; Deputy Executive Director Hilary Nixon, PhD; Graphic Designer Alverina Eka Weinardy; and Executive Administrative Assistant Jill Carter.

Cover image source: https://busride.com/tag/nina-babiarz/. 


\section{TABLE OF CONTENTS}

$\begin{array}{lr}\text { Executive Summary } & 1\end{array}$

I. Introduction $\quad 3$

The Southern California Regional Transit Training Consortium 3

Changing Workforce Needs of the Transit Industry 4

Significant Takeaways $\quad 5$

$\begin{array}{ll}\text { II. Methodology } & 7\end{array}$

$\begin{array}{lr}\text { III. Findings } & 8\end{array}$

Focus Group $\quad 8$

Phone Interviews $\quad 9$

SCRTTC Retreat 10

SCRTTC Successes 11

Survey Responses 11

$\begin{array}{ll}\text { IV. Policy Practices and Recommendations } & 19\end{array}$

$\begin{array}{ll}\text { V. Conclusion } & 24\end{array}$

$\begin{array}{ll}\text { Appendix: SCRTTC Course Catalog } & 25\end{array}$

$\begin{array}{ll}\text { Abbreviations and Acronyms } & 27\end{array}$

$\begin{array}{lr}\text { Endnotes } & 28\end{array}$

$\begin{array}{lr}\text { Bibliography } & 29\end{array}$

$\begin{array}{ll}\text { About the Authors } & \mathbf{3 0}\end{array}$

$\begin{array}{ll}\text { Peer Review } & 31\end{array}$ 


\section{LIST OF FIGURES}

1. Survey Respondent Distribution by Industry Role 12

2. Survey Respondent Distribution by Number of Years in the Industry 13

3. Survey Respondent Distribution by Industry Role Impressions of SCRTTC 13

4. SCRTTC Website Usage 14

5. Survey Respondent Favored Assessment Methods 16

6. Skills Survey Respondents Found to be Lacking in the Current Industry $\begin{array}{ll}\text { Workforce } & 17\end{array}$

7. Technical Workforce Needs Identified by Survey Respondents 18

8. Current SCRTTC Website Homepage Menu Items 20

9. An Example of an Online Community Question-and-answer Forum, Quora 21

10. An Example from the Southwest Transportation Workforce Center of Visualizing the Location of Training Opportunities 


\section{EXECUTIVE SUMMARY}

The State of California SB 1, via the Trustees of the California State University and the California State University Transportation Consortium, funded the Center for International Trade and Transportation (CITT) at California State University, Long Beach (CSULB), to conduct a training needs assessment and gap analysis of the Southern California Regional Transit Training Consortium and its user base. This report seeks to capture the needs of the evolving transit workforce that SCRTTC serves and to assess the broader implications of a changing workforce for the transit industry. The focus of this assessment was to develop SCRTTC strategic priorities through research and engagement in survey, interview, workshop, and focus-group formats.

The research team coordinated with SCRTTC and other leaders in transit workforce development to hear directly from maintenance managers, technicians, and other transit maintenance professionals to document their most pressing skills gaps and critical needs. Throughout, this assessment identifies future training priorities within the context of transformational technological and socioeconomic trends impacting the U.S. transit sector.

Every year, technicians throughout California maintain and repair tens of thousands of buses, cars, trucks, and rail cars throughout the state. Developing training that is responsive to the needs of the transit training workforce means striking a balance between ongoing training demands and the new skills and competencies required to address new technologies. Many of the specific training needs identified in the 2016 Transit Workforce Training Needs Assessment conducted by SCRTTC remain relevant. Training needs were identified in areas such as Cummins 8.9, Electrical Series, HVAC I, and HVAC II. This report highlighted that there are varying boundaries for many SCRTTC members in gaining access to these training programs. ${ }^{1}$ These findings indicated the needs of technicians within the transit industry for more access to the training and development that SCRTTC provides.

The methods utilized in this report were primarily qualitative with the use of a series of interviews, a focus group, a workshop, and an online survey. Prior to data collection, the team conducted baseline research into current training practices and industry standards. The survey component of the methodology obtained approval of its data collection methods from the CSULB Institutional Review Board (IRB). Participants were gathered from member and contact lists provided by SCRTTC and included a variety of industry workers within the transit industry, from technicians up to $\mathrm{C}$-suite. This pool of respondents included both members and non-members of SCRTTC, which allowed for a diverse perspective from the respondents on topics that include general work experience, the state of the transit industry, and SCRTTC's adequacy as a training consortium. The survey was distributed consortiumwide and externally to non-member transit operators. These surveys were then followed up via a series of in-depth interviews (IDIs) that aimed to obtain more personalized insights on the perspectives of transit maintenance managers and technicians.

The findings of this assessment suggest that users are satisfied with current SCRTTC training offerings. However, the findings also suggest a need for more opportunities to engage with the technician user base. Within the focus group, the overall state of the transit industry was rated as generally "fair" by respondents, which was attributed to the significant growth 
within the transit industry as well as the need for workers to continually develop skills in order to meet the needs presented by emerging technologies. There was also considerable discussion about incorporating pedagogical skills as well as apprenticeship and/or mentorship programs that will aid transit workers in learning more diverse workforce-readiness skills as well as technical knowledge.

Current trends in the transit industry indicate a development toward technologically advanced modes of transport, especially related to electrification and hydrogen fuel-cell operated vehicles. With that in mind, the findings indicate that there is a need for more direct and personalized engagement with the technician user base. Those findings suggest the need for the development of an online and mobile-friendly community integrated with the current SCRTTC website that features a suite of digital products that will foster interactivity between transit agencies, training partners, and SCRTTC management. Incorporating customer relationship management (CRM) platforms into the community and housing them within SCRTTC allows consortium management to curate shared content and develop a method of continually assessing the needs and gaps of the industry based on the issues technicians most often encounter. 


\section{INTRODUCTION}

What follows is a comprehensive, statewide transit training needs assessment and gap analysis report for SCRTTC. The report provides an assessment of transit training priorities within the context of transformational technological and socioeconomic trends shaping the U.S. transit sector. This report recommends curricular, programmatic, policy, and technological priorities for the SCRTTC board and leadership to consider as part of current and future training and workforce development initiatives.

This report will also serve as the source text for a 2020 Workforce Development webinar that will be available to transit agencies, community colleges, and other stakeholders aligned with transit workforce training. Feedback from that webinar will inform the completion of a peer-reviewed article in a transportation and policy journal.

CITT will disseminate report findings to state, regional, and national audiences through the communications channels and partnerships developed through CITT and the National Network for the Transportation Workforce (NNTW), as well as the Transportation Research Board's Standing Committee on Education and Training (ABG20).

The focus for this needs assessment and gap analysis is to document and determine SCRTTC priorities to ensure that the incumbent and future transit workforce is equipped with the technological skills needed to meet the demands of an evolving industry.

\section{THE SOUTHERN CALIFORNIA REGIONAL TRANSIT TRAINING CONSORTIUM}

SCRTTC was founded in 2004 by Dave Stumpo and a consortium of transit training experts from industry, government, and education. Finding a lack of consistent training opportunities and course materials across the wide variety of transit agencies in southern California, the SCRTTC team created a consortium of transit agencies and community colleges dedicated to bringing a high standard of non-duplicated training resources to transit operations teams throughout southern California. By pooling funding and educator resources, SCRTTC hoped to improve the quality and consistency of training across Southern California, allowing for the creation of courses through the community college system. This would formalize the trainings offered to technicians and give employees of smaller agencies access to the same quality of technical education provided by larger transit agencies. Currently, the SCRTTC membership includes 57 organizational members composed of regional transit agencies, private organizations, and community colleges across California. Member agencies stretch as far north as Fresno Regional Transit and Golden Gate Highway and Transportation District, and they include organizations as large as LA Metro and Long Beach Transit. SCRTTC enjoys widespread state support and is funded by a combination of federal, state, and local funding, membership fees, and in-kind donations and funds such as the Jim Ditch Education Fund. ${ }^{2}$

SCRTTC is led by its board of directors and six working committees. Chairpersonship of the board rotates between a transit leader and an academic leader every two years, demonstrating the consortium's dedication to creating a collaboration between the two industries. Working committees focus on the direct needs of the organization, such as developing alternative 
fuel engine curricula or securing grant funding for the consortium. These roles are primarily volunteer, and they reflect the dedication of the consortium members to the goal of furthering education for future and incumbent transit workers. Paid positions include the executive director, responsible for overseeing all operations, and the training director, whose role involves the coordination of all academic programming. ${ }^{3}$

Currently, SCRTTC offers classes based on five tracks. The first four tracks increase in complexity, with the first track offering classes on Volt Ohm Meter usage; the second track offering a variety of general courses such as brakes, doors, bodies, electrical systems, and engine and transmission maintenance; the third track focusing on advanced concepts such as HVAC, hybrid vehicle training and safety, and diagnostics; and the fourth track offering more specific advanced training in safety courses, zero-emission buses (ZEB)s, advanced diagnostics, and leadership skills. The final track, track 5 , offers several courses from the other four tracks in an online or blended setting. See Appendix for a full list of courses. ${ }^{4}$ As part of a response to their periodic Needs Assessment and Gap Analysis, SCRTTC is constantly updating, eliminating, and honing the classes offered to ensure they are addressing the needs of technicians and leaders most closely. ${ }^{5}$

\section{CHANGING WORKFORCE NEEDS OF THE TRANSIT INDUSTRY}

Identifying and assessing the future skills gaps and needs facing the transit maintenance workforce cannot be accomplished solely through reviewing historical labor market data. The Bureau of Labor Statistics (BLS) has a repository of Standard Occupational Codes (SOCs) that apply to established transit maintenance occupations. However, it is not possible to find assigned SOCs for emerging transit occupations, and many of the competencies associated with existing SOCs do not account for new competencies required to address transformational technologies. For example, electric bus technicians are often categorized under SOC 49-3031.00 "Bus and Truck Mechanics and Diesel Engine Specialists" because a more appropriate SOC has yet to be developed. Indeed, such limitations associated with historical labor market information for the transit maintenance sector underscore the value of the skills gap and needs assessment in this report. Through interviews and a focus group with maintenance managers and technicians, a workshop with SCRTTC board members and staff, and a comprehensive needs and skills assessment survey, this report provides missioncritical priorities suggested by the research. This report also identifies transformational trends and related recommendations seeking a common goal: to equip SCRTTC leadership and members with a comprehensive assessment of near- and long-term skills gaps and needs facing the transit workforce.

One near-term and long-term concern is that fixed route transit providers are experiencing declines in ridership. The Los Angeles Times reported a $25 \%$ decline in transit ridership in southern California due to slower speeds of buses, lack of reliability, and a rise in car ownership in populations previously incapable of buying a car. To counteract the decline, transit operators are implementing bus-only lanes to improve speeds and are adding more bus stops on routes near strategic locations such as grocery stores and daycares to improve accessibility. ${ }^{6}$ Transit operators are also responding to evolving consumer preferences for mobility options after the rise of Transportation Network Companies (TNCs) like Uber and Lyft. TNCs have redefined consumer expectations and 
are compelling transit operators to develop alternatives to fixed-route options. Transit operators are piloting microbus service models that integrate ride-sourcing services into public transit offerings. Transportation researchers exploring these trends are increasingly finding that micro-busing technology offers ways for transit providers to reduce operating costs and enhance last-mile transit connectivity. ${ }^{7}$

As microtransit increases in popularity to meet new consumer demands for flexibility and accessibility, these new, nimbler transit services will redefine notions of modern mobility. ${ }^{8}$ Those microtransit trends will require fleets of smaller and smarter buses. These new bus fleets will require updated training curricula and programmatic offerings. New training will also need to be developed to address increases in electric and hydrogen fuel-cell bus fleets.

Current common practices for technician training are limited in availability and flexibility of content, particularly courses on emerging technologies. Some OEMs provide familiarization training to technicians at the time of purchase of the new vehicle. Other resources include web-based training materials and curricula at community colleges and trade schools.

Moving forward, information technology (IT) management competencies will also become necessary across the transit workforce as project management tasks and workflows are increasingly digitized. In the longer term, IT competencies will become more relevant in transit maintenance as maintenance schedules developed by original equipment manufacturers (OEMs) are integrated into project management systems to improve efficiency and document accountability. Such an approach marks a new era in transit maintenance operating systems. In this new era, procedures are developed to support networked systems for vehicular and infrastructure maintenance that facilitate micro-transit functionality, quality-control metrics, next-generation energy needs, and other mission-critical priorities.

\section{SIGNIFICANT TAKEAWAYS}

The catalog of existing SCRTTC training curricula is well-respected, and there is strong demand for additional topics. In interviews with industry practitioners and training partners, a focus group with transit technicians, and a comprehensive online survey, transit maintenance professionals consistently endorsed the value and quality of SCRTTC training-they just want more of it. They want it to be developed more efficiently and at a higher volume. They seek more localized and customized delivery methods for training and curricula.

Another major takeaway is that both members and nonmembers agree that SCRTTC should expand throughout California. One obvious justification is that the consortium footprint already includes members in northern California. Statewide expansion strikes a middle ground between those members who support developing a deeper focus in southern California with those who favor a more ambitious national expansion. By focusing on expanding statewide, but stopping short of national expansion, a proposed "California Transit Training Consortium (CTTC)" could emerge. A CTTC would be scalable and provide a path for a phased state-by-state expansion to ultimately establish national representation. Such an approach would draw from the SCRTTC/CTTC playbook to address local, regional, and national training needs that are compatible with the policies, regulations, and socioeconomic realities that are unique to each state. Additionally, despite the purview 
of the report being to assess current SCRTTC curricula and practices, stated needs and suggestions gathered in the workshop, focus group, and interviews revealed a need for broader curricula and more of a technician community. Thus, further recommendations include the integration of a suite of scalable digital products that would facilitate official expansion to all of California and later other U.S. states. 


\section{METHODOLOGY}

The research team conducted the study primarily through qualitative methodology, using a series of interviews, a focus group, a workshop with SCRTTC board members and staff, and an online survey. The process began in May 2019 with pre-workshop interviews with SCRTTC management. Following the pre-workshop interviews, a workshop was facilitated asking SCRTTC board members a range of questions to gauge perceptions of the state of the transit industry, the role of SCRTTC in the industry, and their sense of the current efficacy of SCRTTC as a training consortium and regional leader. Following the workshop, post-workshop interviews were conducted in October 2019 with SCRTTC management to assess how the workshop had influenced their perceptions. The research team also interviewed former SCRTTC members, transit maintenance managers and technicians, original equipment manufacturers (OEMs), and survey respondents who opted to share more of their perspective.

To gain a better understanding of the public's view of SCRTTC, an online survey was distributed to a variety of industry workers, including executive level workers, middle management, technicians, educators, and other industry workers. A survey instrument was developed and submitted for approval through CSULB's IRB. Prior to participating in the survey, all respondents consented to participate, in compliance with IRB requirements. Responses were collected over the course of several months, from September to December 2019. A total of 73 respondents opened or began the survey, and 42 respondents submitted usable responses for analysis. Industry roles for respondents were diverse, and they included C-suite employees, middle management, transit operators, education service providers, and other industry members such as a DOT worker and a Mobility Planning Operator. Questions were asked about training needs, on-the-job experiences, the state of the transit industry, and SCRTTC's efficacy as a training consortium.

Finally, on December 10, 2019, a virtual focus group was conducted with three transit technicians and managers. Participants were asked about their sense of the transit industry overall, their knowledge of SCRTTC, and their assessment of current needs for transit operators, trainers, and transit agencies. 


\section{FINDINGS}

\section{FOCUS GROUP}

The focus group opened with a general discussion of the state of the transit industry, which was rated by all respondents as generally "fair." This result was attributed to the significant growth within the transit industry, as well as the learning curve involved with continuous technological enhancements. Members of the focus group also pointed out that the state of public transit is highly dependent on location, with cities like San Francisco or New York being better developed than other less developed markets.

When discussing SCRTTC, participants generally lacked familiarity with the consortium. This finding is consistent with survey responses, which indicated that the majority of respondents were not aware or only peripherally aware of SCRTTC as an organization. Those who did have familiarity with the organization-both in the survey and in the focus group-found it to be a useful organization that delivered effective, relevant curricula.

Technical training needs discussed during the focus group included:

- electrical code training,

- computer network training,

- diagnostic tool training, and

- electric meter training.

Electric and hydrogen fuel-cell training were also identified as important course offerings. Other participants felt that SCRTTC would do well to offer more rail-focused curricula. In addition to technical skills, focus group participants stressed the need for broader projectmanagement skills such as troubleshooting skills, how to efficiently navigate and use service manuals, and pedagogical skills like how to incorporate technical literature into instructional training. In terms of general industry training needs, three main themes emerged in the focus group: soft skills or employability training, pedagogical training, and project management.

Soft skills training needs for technicians and instructors were echoed by all respondents and included things like communication, leadership skills, and the development of good judgement. Specifically, one respondent spoke about the need to develop skills in independent critical thinking, where and how to seek out information when it is needed, and how to apply principles of training practically in troubleshooting situations. The need for an emphasis on soft skills training within project management curricula was also mentioned.

Pedagogical skills were also discussed as a primary industry need. Respondents felt their agencies would benefit from effectively incorporating modern instructional practices, such as incorporating active learning in the forms of modeling and practice, and in the use of technology in training such as videos, PowerPoint presentations, and 3-D modeling. Discrete pedagogical skills such as creating pre/post assessments, learning how to develop curricula 
from training manuals, creating lesson plans and objectives, and creating content, along with facilitation skills, were all listed as important competencies that would empower trainers to educate others.

Respondents also discussed incorporating an apprenticeship or mentorship model as an essential part of any training curriculum. Technicians expressed support for training models derived from apprentice training best practices that involve instruction and observation along with active practice that is observed and corrected. ${ }^{9}$ Such approaches involve a teaching phase where concepts are taught in a classroom setting followed by visual models and a practical phase where technicians would work independently, but under very careful supervision or paired with a peer. This type of mentor or journeyperson training was echoed in the survey responses as being an important aspect of successful technician training.

\section{PHONE INTERVIEWS}

Phone interviews proved useful in validating findings from the SCRTTC board member workshop, the technician focus group, and the survey instrument used to shed light on the skills gap and needs assessment in this report. Interviews were conducted with SCRTTC staff, former SCRTTC members, current members, and representatives from OEMs.

Representatives from OEMs, transit operators, maintenance managers, and technicians all agreed that there is currently a disconnect between the initial familiarization training provided by OEMs and the ongoing maintenance training required to maintain and upskill the transit technician workforce. That disconnect was also noted by several survey respondents. This assessment confirmed that few curriculum developers exist at the transit agency level. However, survey respondents and interview subjects stated that pedagogy and curriculum development are skill sets that agencies would find extremely useful for their trainers, especially since the training materials often amount to technical manuals provided by OEMs that do not include any formal curriculum. This lack of formal technical curricula represents a critical need for the transit maintenance workforce. That need suggests an opportunity for SCRTTC to work with OEMs and transit agencies to develop training resources that help bridge the gap between OEM familiarization training and the technician training required to operate and maintain transit bus and rail technologies.

Phone interviews with maintenance managers revealed another common narrative. In several cases, maintenance managers noted that they joined SCRTTC after the retirement of a trusted in-house trainer. In lieu of an in-house trainer, the managers sought to address their training needs via SCRTTC curricula and programs. In that context, maintenance managers acknowledged the value of SCRTTC training offerings but also stressed a desire for more on-location training as well as a broader library of training and curricular options. Managers also noted that the hands-on mentoring and train-the-trainer qualities provided by their previous in-house trainers were not found to the extent that they desired in current SCRTTC offerings. Interviewees noted that mentoring and train-the-trainer formats made it easier to integrate soft skills, project management, and other employability skills.

Several interviewees suggested that SCRTTC could address the capacity challenges associated with providing more technical training offerings by increasing the development of 
Web-based training models. Here, it is worth noting that SCRTTC's success with delivering their Digital Volt Ohm Meter course online indicates constituents' desire for distancelearning offerings and validates the value of developing more online technical curricula. One interviewee noted that the automotive industry was an innovative early adopter of Webbased training and suggested that SCRTTC explore ways to apply successful online training methods from that sector to the transit maintenance sector. Another interview subject noted that employing more online training formats would reduce the number of days missed by transit employees for training purposes.

Interview subjects acknowledged the unprecedented rates of transformational technology reshaping the transit sector. They emphasized a need for more rapid evaluations of training needs to prepare for fleets of hydrogen fuel-cell and high-voltage electric buses. There was clear consensus among participants in interviews, surveys, the workshop, and the focus group that that skills gaps were being created in the transition from combustible-engine bus fleets to electric and hydrogen fuel-cell-based bus fleets. That consensus strongly suggests that SCRTTC develop training curricula to address skills gaps related to the transition to zero-emission bus fleets.

In order to respond to a range of training needs, interviewees also noted that SCRTTC should consider offering a spectrum of training offerings ranging from short one-hour tutorials to multi-day modules. Others expressed a desire to tackle emerging technologies, proprietary issues, and other complex transit maintenance concepts.

A clear take-away from the phone interviews was that the SCRTTC user base seeks a broader variety of training products and related delivery methods. Such feedback signals a need for portable online training options delivered via video and webinars along with the creation of online communities to address other transit maintenance topics more suitable for a discussion than a formal training session.

\section{SCRTTC RETREAT}

On May 14, 2019, SCRTTC convened at Los Angeles Trade Technical College for its annual board member retreat. The 2019 retreat featured an organizational workshop facilitated by CITT Director of Research and Workforce Development, and one of this report's authors, Tyler Reeb. The workshop began with group discussion led by Dr. Reeb that included SCRTTC board members and staff. That initial session was followed by a closed-door session without SCRTTC management.

\section{Board's Assessment of Transit Industry}

The general consensus was that the overall state of the transit industry is generally "fair" to "good." Board members noted that interconnectivity between transit organizations is an issue for riders. One of the most frequently mentioned issues was that transit agencies are having trouble recruiting workers. SCRTTC board members stated that retention is not the problem, but rather an aging workforce is retiring in waves and there is greater competition for labor with other industries. Other frequently mentioned issues were that transit agencies need to consider Uber and Lyft as partners rather than the competition. Board members also 
mentioned that each community is different and needs to be evaluated uniquely. Several board members noted that one important factor to consider, and one that can vary widely from agency to agency, is differences in first- and last-mile transit conditions. First- and lastmile conditions are shaped by urban, suburban, exurban, and rural realities.

\section{SCRTTC SUCCESSES}

Most members stated that SCRTTC is effective in compliance training and training for new technologies, and thus the consortium needs to make sure it stays at the forefront of technological progress. There was also consensus that the distance-based approach is effective at reaching a broader audience.

\section{SCRTTC Opportunities for Improvement}

SCRTTC should improve upon its training for customer service skills. The consortium can look for opportunity in sharing training burdens with other industries where there is overlap, training new hires for "workplace readiness," supervisor training, and marketing the industry to the younger generation.

Members' consensus was that current management personnel are stretched too thin and struggle to provide visible and accessible leadership throughout the California transit sector. A majority of board members expressed support for a democratically reaffirmed mission statement for SCRTTC. The goal of such a reaffirmation process would be to consider what role SCRTTC should play in support of the California transit workforce. Such roles to consider include education, training, advocacy, and lobbying. Other mission-critical considerations include whether SCRTTC should focus on all current and future transit modes including rail, or only buses.

\section{SCRTTC Looking Forward}

A majority of board members voiced support for dropping the "S" in SCRTTC to signal that the organization already has a statewide reach. Other board members asserted that SCRTTC needs to plan for what happens when the current CEO leaves, and also that SCRTTC should bring on at least one more full-time employee in order to handle the needs of the consortium as it grows.

Many members identified that statewide expansion was an important indicator of success for SCRTTC. The consortium may subsequently be able to expand nationwide, a step which was included as part of the original plan for the consortium. Some members mentioned that the industry's success is indicative of SCRTTC's success.

\section{SURVEY RESPONSES}

Responses for the SCRTTC skills gap and needs assessment survey came from different sectors of the transit industry, both inside and outside SCRTTC. Non-SCRTTC member transit operators made up the majority of respondents. Respondents who answered "Other" identified with such occupations as Maintenance Supervisor, Education Trainer, SCRTTC 
Administration, Transit Bus Supervisor of Maintenance Training, Technical Trainer, and NonSCRTTC Regional Planner (see Figure 1). There was a total of 73 survey responses, a number of which were incomplete, leaving the official count of respondents at 41 . However, there are less than 41 responses for each question because respondents had different questions based on whether they were from an education service provider or a transit operator. Therefore, there was not a large enough survey sample to claim overall trends but rather to instruct input for our research that synergized with the findings of the retreat, focus group, and interviews.

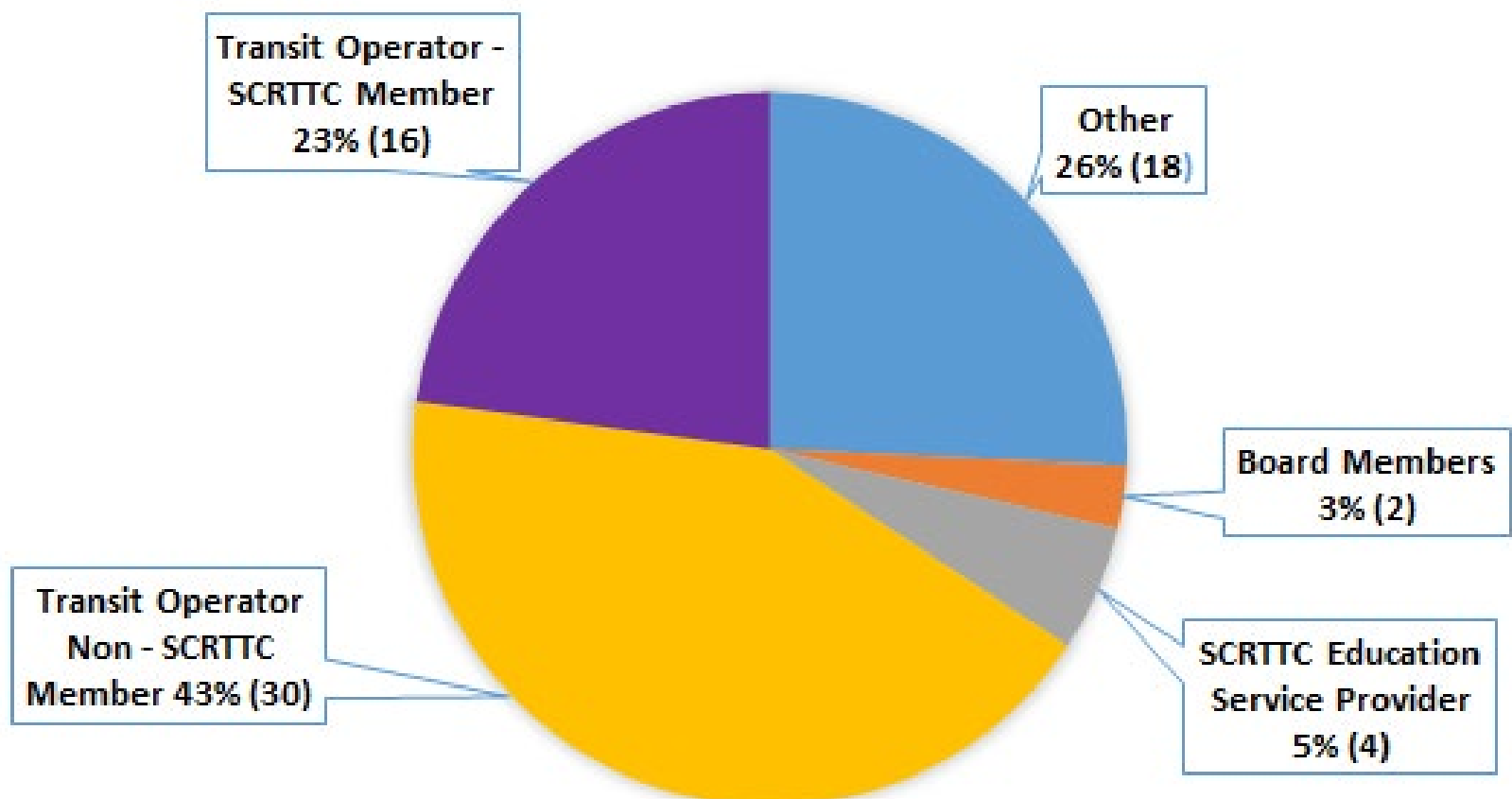

\section{Figure 1. Survey Respondent Distribution by Industry Role}

Respondents who were transit industry employees with more than 20 years of experience totaled $42.50 \%$, while transit employees with between 10-20 years of experience made up $30 \%$. Of all respondents, $7.50 \%$ had $7-10$ years of experience, and $12.50 \%$ of respondents had 4-6 years of experience. Respondents with 1-3 years of experience totaled $7.50 \%$ (see Figure 2). 


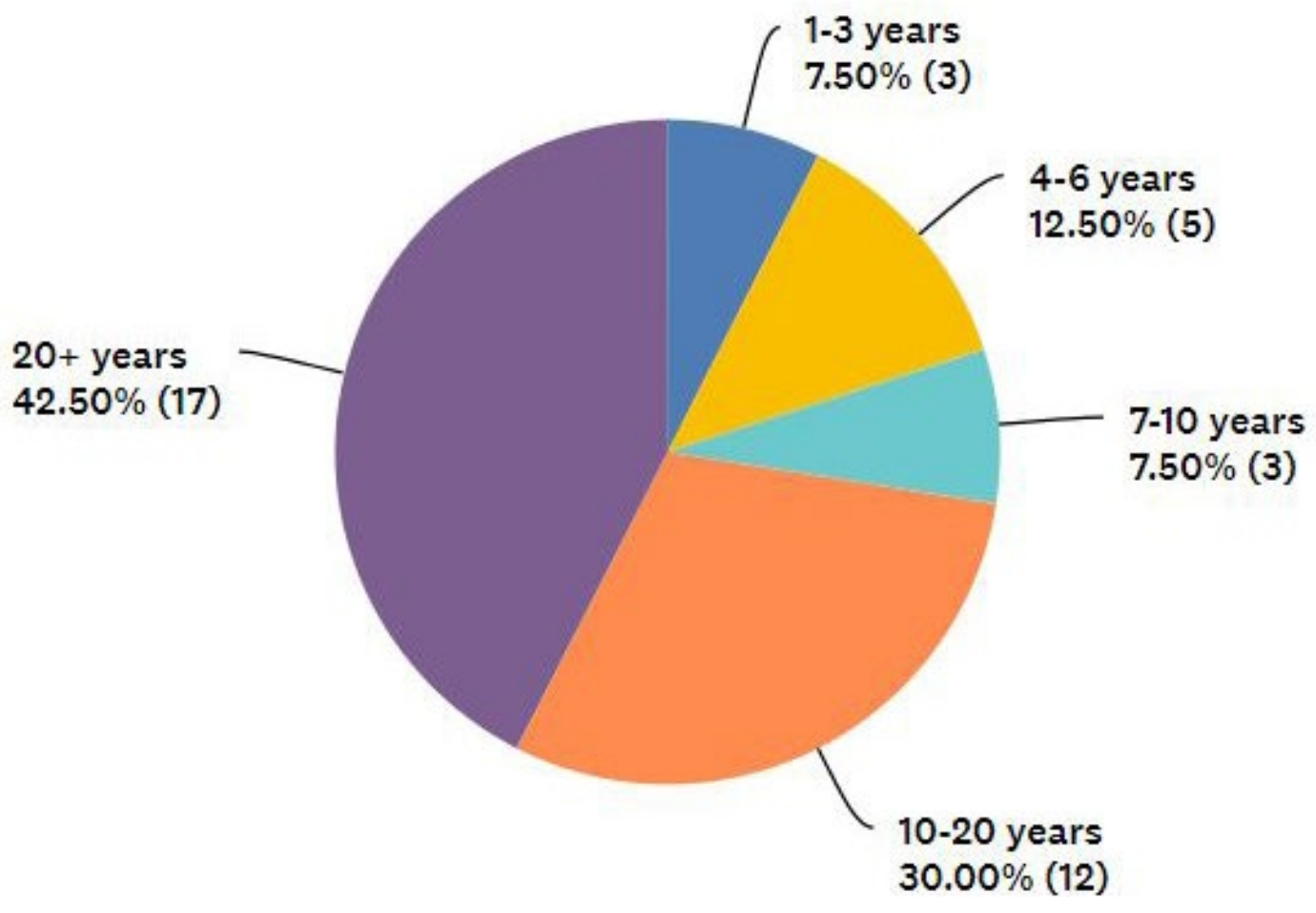

Figure 2. Survey Respondent Distribution by Number of Years in the Industry

Only $5 \%$ percent of respondents identified as C-suite executives, while upper management employees made up more than half of the respondents ( $52.50 \%$ : see Figure 3 ). Maintenance workers made up $35 \%$. Respondents' bus fleets varied considerably in number, ranging from only a few to hundreds.

Which of the following categories pertain to your specific work duties? (Please select one)

Answered: 40 Skipped: 33

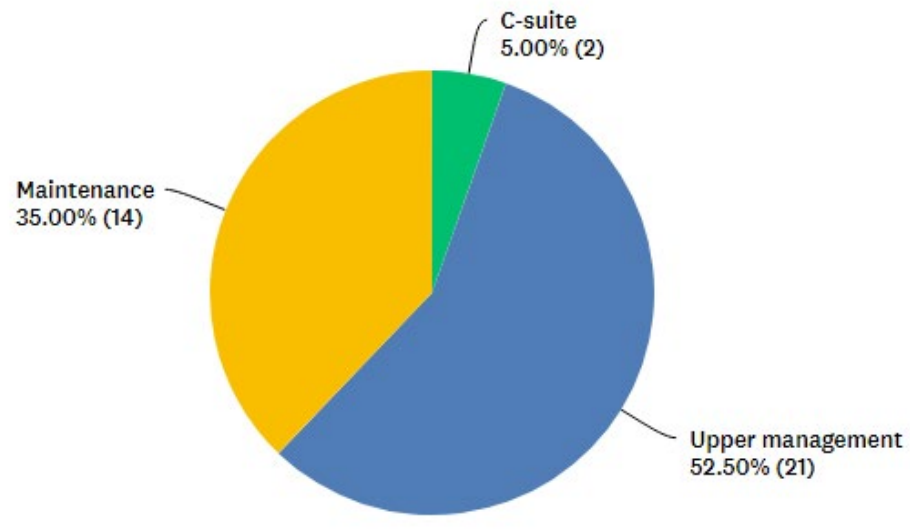

Figure 3. Survey Respondent Distribution by Industry Role Impressions of SCRTTC

Of the total respondents, only $44 \%$ were aware of SCRTTC prior to taking the survey. Participants who were aware of SCRTTC overall reported engagement with the organization, 
with $72.73 \%$ of those respondents reporting having previously sent employees to SCRTTC trainings. Courses that participants had attended included Integration of Intelligent Transportation Systems (D1-DVOM/ITS Technologies), E1-Electrical I for Transit, Network Electronics Diagnosis and Repair (E3-Electrical III for Transit), PLC/IO Systems Diagnostics (E4-Electrical IV for Transit), Project Management, and Introduction to HVAC for Transit (eHVAC I).

Participants were also asked about their experiences with the SCRTTC website. Website use was reported by $60.87 \%$ of respondents, and all participants who reported using the website found it met their needs. Participants were also able to indicate how they used the website (see Figure 4); more than two-thirds of respondents reported course registration, $14.29 \%$ used it to learn about other members, $42.86 \%$ opted to learn more about SCRTTC, $21.43 \%$ reported using the website to donate to the Ditch Fund, $50 \%$ chose to look at training materials, $28.57 \%$ read the newsletter, $21.43 \%$ viewed the annual report, $14.29 \%$ reported using it for other general training-related reasons, and $7.14 \%$ viewed other publications.

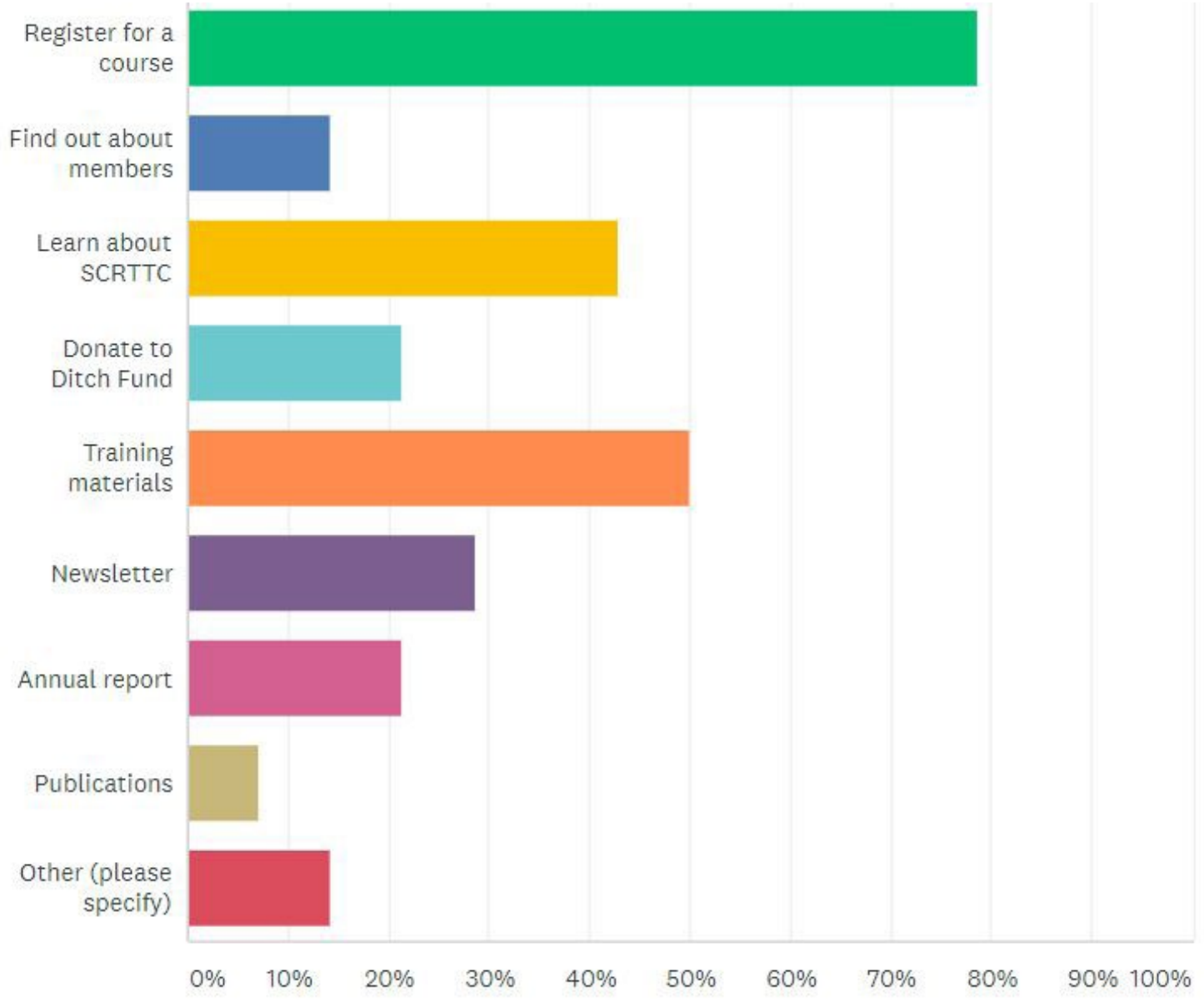

Figure 4. SCRTTC Website Usage

Regarding perceptions of SCRTTC, participants reported very positively on the organization, with $64.71 \%$ of respondents finding the consortium to be successful overall. Membership fees were described as "adequate" by $75 \%$ of respondents and "too high" by another $25 \%$. Trainings offered by the consortium were described as high-quality, well-organized, and relevant and applicable to their daily work. Training was seen as highly beneficial for incumbent workers, particularly in the area of maintenance and technical skills. The opportunity to interface with 
other workers and troubleshoot in a true learning environment without supervisory pressure was noted as a valuable use of trainees' time. Reported challenges with the training were limited to individual responses that did not have overarching themes. One respondent complained that the course exam tested some material not covered in the class. Another respondent reported technical difficulties with an online class.

The primary recommendations to improve SCRTTC training focused on a demand for a broader range of training offerings that were accessible at varied locations. However, several recommendations were also offered on improving current and future content. Respondents affirmed that online training was a critical delivery vehicle for training that warranted continued as well as new and extended offerings. Some respondents also noted the importance of increasing labor union involvement to improve technician buy-in and ensure that SCRTTC classes are addressing worker needs. Respondents were also asked to provide recommendations for future classes, which included ZEBs with electric and hydrogen-fuelcell drive trains. Respondents also voiced continued support for mechanical trainings on brakes, transmissions, bus doors, air conditioning certification, and California Highway Patrol inspection. Management and train-the-trainer courses were also recommended, with respondents specifically citing curriculum development, class planning, classroom assessment, and the incorporation of technology into trainings (PowerPoint, 3-D modeling, iPads, smart boards) as essential parts of trainer education.

\section{Future Industry}

The majority of responses concerning the future of the transit industry focused on the growing prevalence of ZEBs and information technology (IT) systems connected to the respondents. Respondents reported that changes driven by the introduction of new IT systems and ZEBs were major factors affecting training needs. One respondent stated, "new technology will require more training and for formalized programs to be developed such as Automotive Service Excellence (ASE) programs related to clean and ZEB technologies. [...] [B]oth technicians and operations/planner staff need more intelligent transportation systems (ITS) training and engineering backgrounds as ITS systems become prevalent." Respondents reported that ZEB bus and computer training were the most important training topics for mechanics and technicians in particular, relating to the increase in electric vehicles. One respondent emphasized the safety component of implementing electric vehicles, particularly the "safety practices around high voltage systems, batteries, etc."

\section{Present Training}

Respondents were also asked about their agency's current training practices and needs. Most respondents stated that their organization's training needs continually change due to differences between OEMS, although one respondent noted that current equipment purchases tend to include training. Due to constant change, the majority of respondents expect workforce development training to enhance the skills of workers, with some respondents expecting an increase in productivity. Consistent with findings from interviews and a related focus group, other respondents expressed a need from train-the-trainer curricula and training to upskill more entry-level employees. 
When asked about whether their agency funded outside training, $55.17 \%$ responded affirmatively, while $10.34 \%$ confirmed that their agencies did not fund outside education. Another $34.48 \%$ responded that it depended on various requirements from the agency, such as applicability to the trainee's job, whether the training was required for the position, whether the trainee passed the class, and the amount of available funding for that year. Funding for training was described as coming from a variety of sources, with most respondents attributing funding to their agency's budget but also occasionally through grants and local funding. The amount paid or reimbursed for outside training per year ranged from $\$ 1,500$ to $\$ 20,000$, with the amount given depending on factors such as training cost and type of training. A majority of respondents $(73.33 \%)$ reported that their agency has annual spending caps on trainings. Spending caps were reported as ranging from $\$ 1,500$ to $\$ 20,000$.

When asked about what methods they used to determine training needs, respondents selected "regular assessment" as the most commonly cited methodology (see Figure 5). Most respondents $(54.84 \%)$ found in-person training to meet their needs best, while group session training $(22.58 \%)$ was also cited as being a useful method of instruction. Online training $(3.23 \%)$ and organization-wide training $(9.68 \%)$ were found to be useful by a much smaller percentage of respondents.

\section{How do you identify your organization's job skill training needs? (Please check all that apply)}

Answered: 33 Skipped: 40

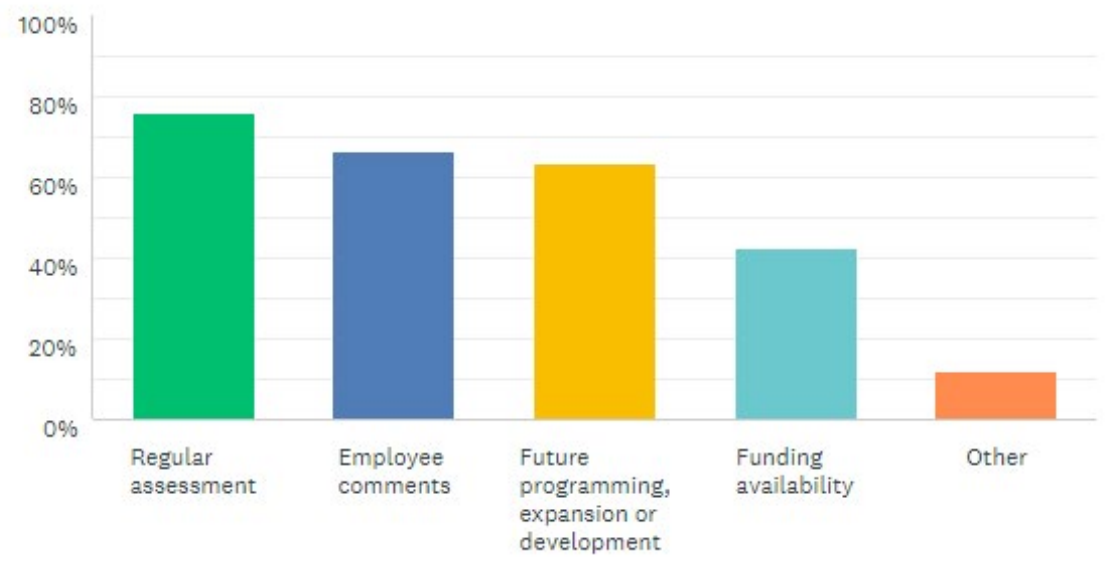

Figure 5. Survey Respondent Favored Assessment Methods

In-house or classroom-based learning was reported as being the best way to meet respondents' agency training needs, with $85.19 \%$ of respondents endorsing those forms of training. Contract training $(62.96 \%)$ and online or distance learning $(59.26 \%)$ were also favored methods. Mentorship programs $(48.15 \%)$, continuing education or certificate programs $(48.15 \%)$, degree programs $(40.74 \%)$, and internships $(37.04 \%)$ were endorsed at lower but still favorable rates.

Maintenance workers were reported as being the primary recipients of training opportunities, as cited by $29.03 \%$ of respondents. Operations professionals were the next largest recipients of training at $22.58 \%$. At $16.13 \%$ and $12.90 \%$ respectively, mid-level management and entry-level workers were also endorsed as being significant recipients of training. Senior 
management $(6.45 \%)$, program and planning staff (6.45\%), and employee retention programs $(3.23 \%)$ were the least likely to be seen as primary training recipients.

Out of a multiple-selection menu of possible assessment methods, respondents chose technical assessments (62.07\%) and participant evaluations (51.72\%) as their most preferred methods of assessment. Career advancement of participants (34.48\%), program completion figures $(24.14 \%)$, and promotion $(24.14 \%)$ were selected frequently as well.

\section{Training Needs}

According to respondents, competition from other transit providers is one of the most prevalent obstacles in carrying out operations in their organization. Such competition causes one agency to "poach" transit employees from other agencies. Other factors, like obtaining public input, lack of flexibility of transportation funds, and lack of ability to find funding for local match or other funding sources were also noted. Respondents reported that project implementation authority, revenue-raising authority/bonding authority, and more board support would improve the effectiveness of transit agencies. Along with issues affecting the operations of the organizations as a whole, the majority of respondents $(59.26 \%)$ also determined that computer/information skills were lacking within the workforce (see Figure 6), along with equipment maintenance $(51.85 \%)$ and electrical trade skills or certification (48.15\%).

\section{Which of the following technical skills would you consider to be lacking in your organization's workforce? (Please check all that apply)}

Answered: 27 Skipped: 46

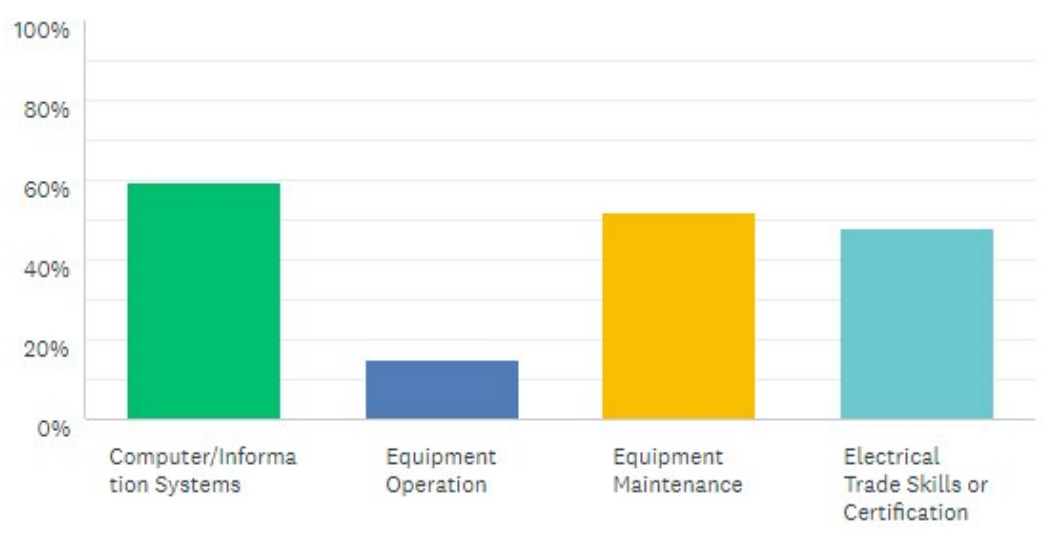

\section{Figure 6. Skills Survey Respondents Found to be Lacking in the Current Industry Workforce}

As needs for future training were discussed, respondents were asked how their organizations maintained relevant training. One respondent answered that the training developed was "determined by organizations' needs analyses, emerging technologies, and new model technical highlights." Another respondent explained that their agency purchased "training in our bus by contracts which includes train-the-trainer on the emerging technologies such as hydrogen fuel cell." 
When assessing the efficacy of training, compliance was listed as the greatest factor considered by respondents. System performance (reliability, accessibility, safety, security, fleet condition, ridership, and so on) as well as perceptions and communications from stakeholders, board members, and the public were also cited as significant factors.

One major change that has affected training curricula has been the differences between equipment providers. One respondent remarked that "many training courses are foundational in nature while others will be specific to the bus procured by a specific transit agency. In the case of battery electric buses, all manufacturers are using different electrical systems and charging systems." The respondent continued, "Many other supplied systems such as doors, brakes, etc. are provided by a few leading suppliers. Some training may be specific to these suppliers' equipment." Another major issue for the majority of respondents is finding training programs, as $66.67 \%$ have encountered identifying training providers. This point speaks again to the visibility challenges SCRTTC may be facing. Lack of funding for training was also identified as a challenge for managers. One respondent also cited the knowledge gap that operators have regarding commercial vehicle law.

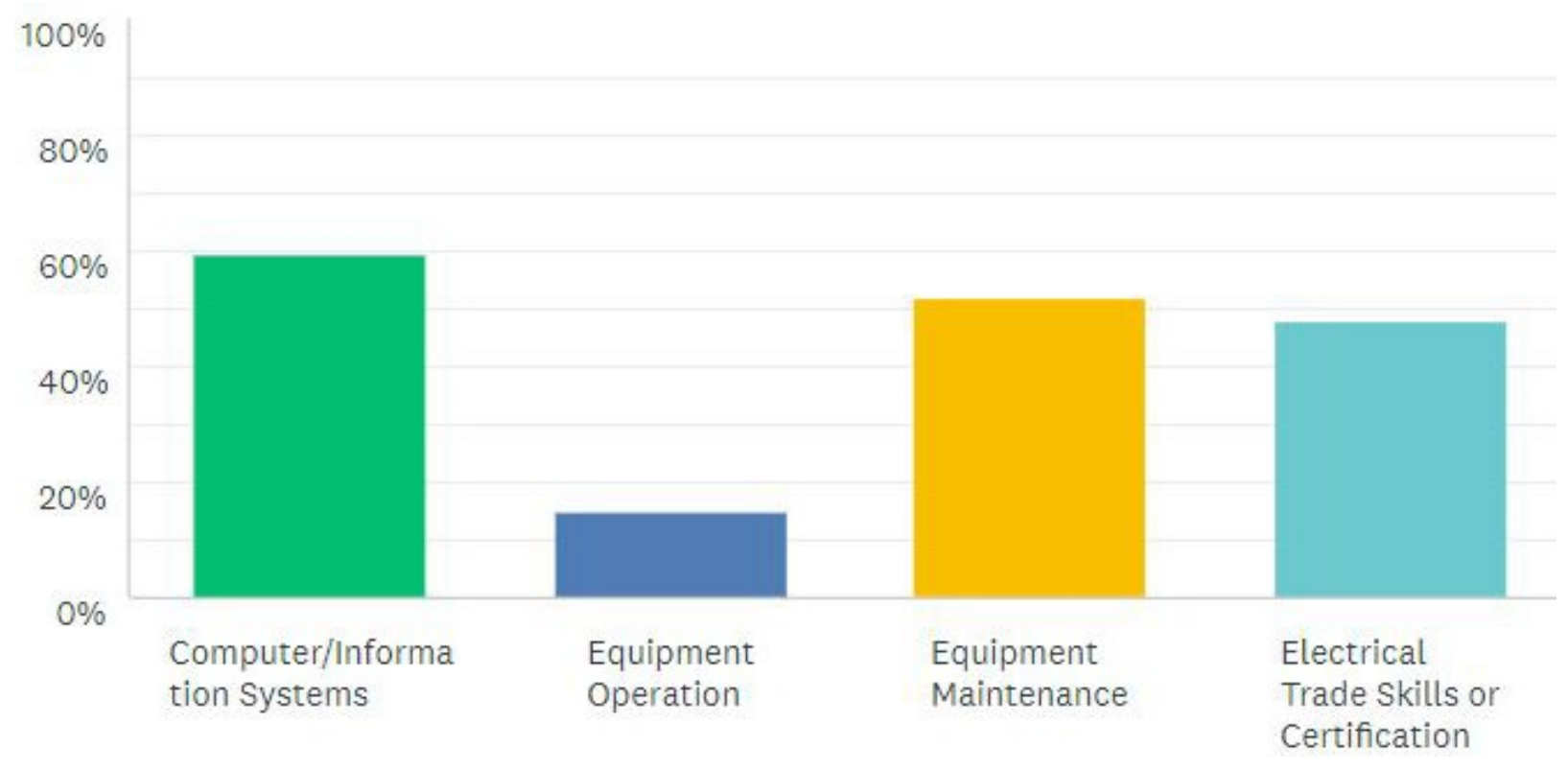

Figure 7. Technical Workforce Needs Identified by Survey Respondents 


\section{POLICY PRACTICES AND RECOMMENDATIONS}

The challenge for every training organization is to strike the appropriate balance between addressing near-term demands and responding to new skills gaps and professional needs driven by transformational trends. Many of the specific training needs identified in the 2016 SCRTTC Transit Workforce Training Needs Assessment remain relevant. In addition to validating existing training priorities, participants who contributed to this 2019 report confirmed that training for all aspects of maintaining vehicular and infrastructure technology related to electric and hydrogen fuel-cell bus fleets are becoming increasingly critical as transit agencies transition to ZEB fleets. Those changing transit workforce realities call for new approaches to developing and delivering technical training needs for electrical code training, computer network training, diagnostic tool training, among many other topics.

To become proficient in these rapidly changing transit technologies, participants who shared insights that informed this assessment expressed a need for training modules that incorporate active learning in the forms of modeling and practice, and in the use of technology in training such as videos, PowerPoint presentations, and 3-D modeling. Participants in this research also consistently expressed a need for resources to facilitate more train-the-trainer activities. Resources to empower trainers to educate others call for discrete pedagogical skills such as creating pre/post assessments, learning how to develop curricula from training manuals, creating lesson plans and objectives, creating content, and facilitation skills.

The findings in this report suggest that the demand for train-the-trainer instruction stems from a need for more onsite training featuring expert observation paired with active-practice curricula for users that is observed and corrected. Such approaches require teaching phases where concepts are first taught conceptually and then later applied in hands-on settings where technicians work independently, but under very careful supervision by an instructor or paired with a peer.

Soft skills training needs were echoed by all respondents and included things like communication, leadership skills, and the development of good judgement. Respondents also emphasized the need for broader project-management skills such as troubleshooting, how to efficiently navigate and use service manuals, and how to incorporate technical literature into maintenance training.

In many respects, the feedback from participants in the interview, survey, board member workshop, and focus group phases of this report indicates that the needs and skills gaps identified in this report have more to do with how SCRTTC develops and disseminates training to the transit workforce than with what the training actually addresses. Respondents approve the topics and quality of existing SCRTTC training - they just want more of it, and they want it produced at a faster rate. In transactional terms, the SCRTTC target audience wants a lot more product, and they want that product to be customized to their local needs. To reiterate, survey responses indicate that users like what SCRTTC has developed, but they are concerned about how the consortium can produce more of it at a faster rate.

The expressed need for quicker development of new training compels the question: How 
can SCRTTC make organizational changes to more rapidly develop curricula and provide targeted training programs for technicians?

Fortunately, there are proven digital tools that can be integrated into the SCRTTC website to help SCRTTC respond to the needs documented in this assessment-namely, more capacity for more training offerings and more online delivery methods while SCRTTC simultaneously enhances its response to member demands for more customized and location-based training.

Although the current SCRTTC website (see Figure 8) was evaluated by respondents as satisfactory and generally meeting their needs, the full scope of feedback from this assessment spotlights ways that proven digital communication and outreach tools can help SCRTTC to improve capacity to offer more diverse training offerings, cultivate a stronger sense of community among its members, and develop a more direct and customized relationship between the consortium and its user base. The recommended digital outreach and communications tools are best characterized as an integrated suite of enterprise resource planning products to improve user engagement and enhance strategic communications.

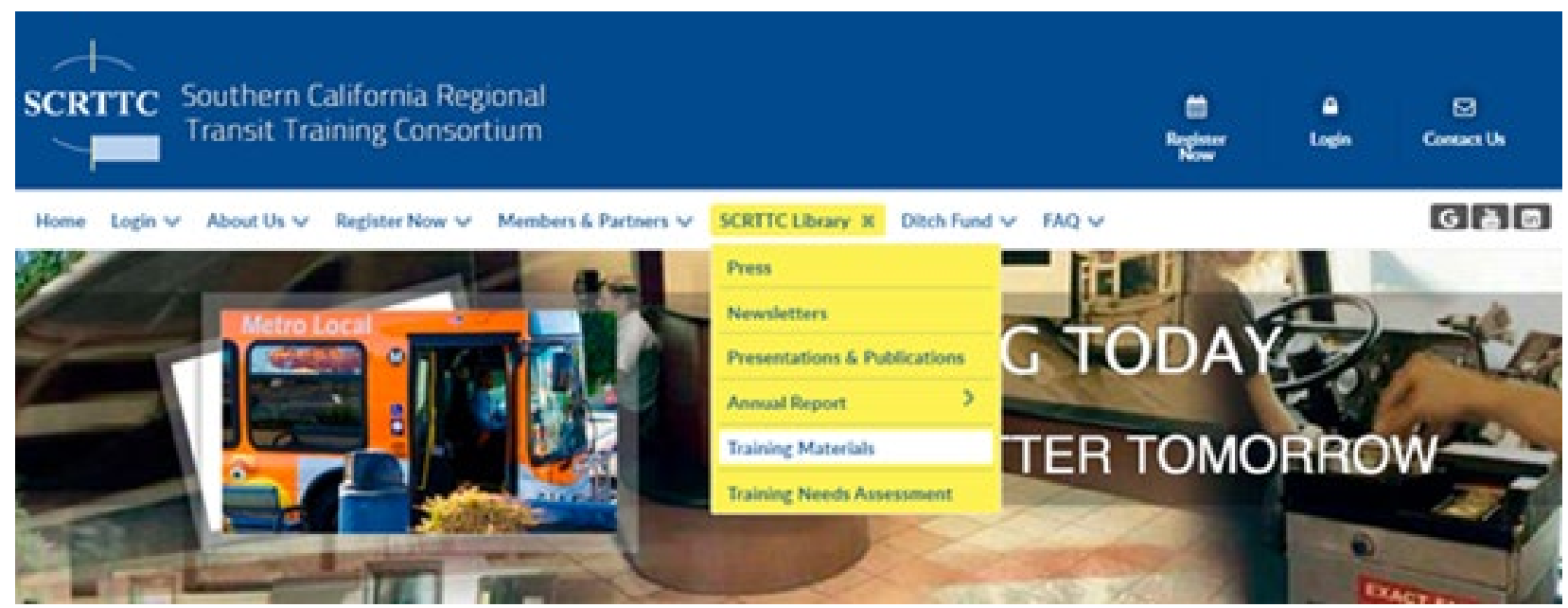

Figure 8. Current SCRTTC Website Homepage Menu Items

Such an approach would begin with the implementation of a CRM platform that would make it possible for SCRTTC leadership and staff to better understand the needs of the transit maintenance user base. CRMs make it possible to create intelligent and versatile customer or constituent databases that empower individual users to establish profiles that feature their most pressing needs and concerns. Establishing a database of user profiles would make it possible for SCRTTC to have a more direct way of identifying training needs. Such CRM functionality would enable SCRTTC to aggregate and assess those training needs to determine the most in-demand skills and needs to address in future training offerings. With the current norm of technicians working without employee email accounts, the system could incorporate a tiered user system with different permissions for technicians versus management. This would provide a way for technicians to have personal accounts with direct and compliant affiliation with their dues-paying employer.

A CRM platform would integrate with the SCRTTC website to make it possible for the consortium to develop new user-facing workforce development digital products that build on in-class and location-based outreach efforts. The integrated suite of recommended digital 
products are as follows:

- The establishment of an online "transit tech expert network" that convenes a community of practice to harness the collective expertise of SCRTTC members and users. The network would feature a community forum (see Figure 9) where members and users can use a question-and-answer format to participate in technology transfer dialogue and share open-source resources. The community forum would also serve as a new source for SCRTTC to document, on an ongoing basis, skills gaps and needs facing the transit workforce.

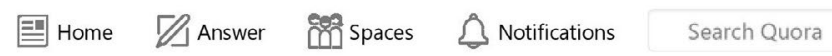

Add Question

Battery Electric Vehicles (BEV) Electric Vehicles +3

Since electric vehicles have much less maintenance (and parts), what will happen to the existing dealer franchise network when EVs become mainstream?

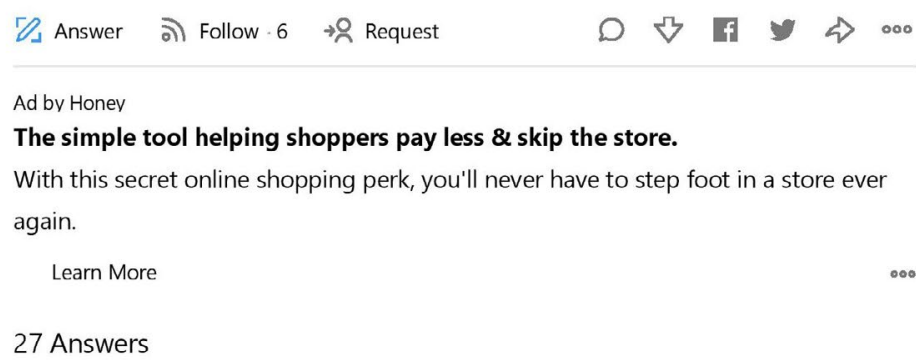

5 comments from Seth Chazanoff, Roger Starkey, Lawrence Liang and more

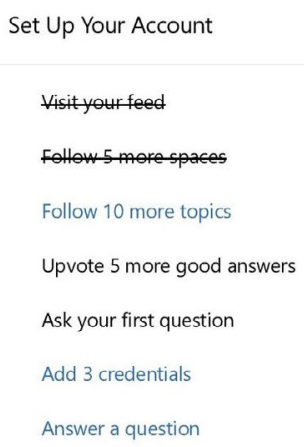

Figure 9. An Example of an Online Community Question-and-answer Forum, Quora

- A periodic video series featuring hands-on maintenance tutorials that technicians can view in a step-by-step format. All member transit agencies would have the opportunity to record and contribute installments in the series. SCRTTC would provide continuity in this series by funding and facilitating the production of 3-4 video tutorials per year. Those productions would be recorded at SCRTTC member locations, which would signal responsiveness to member demand for more localized training.

- A soft skills webinar series hosted live from various member locations, streamed to the network, and recorded for later viewing. 
- OEM and education service provider updates featured on the "transit tech expert network" as an opportunity for those critical partners to provide written or multimedia updates to SCRTTC's user base.

- An annual train-the-trainer contest: technicians, with their organization's consent, upload short video tutorials to the "transit tech expert network" with $\$ 500, \$ 200$, and $\$ 50$ awards given to the top three uploads each year.

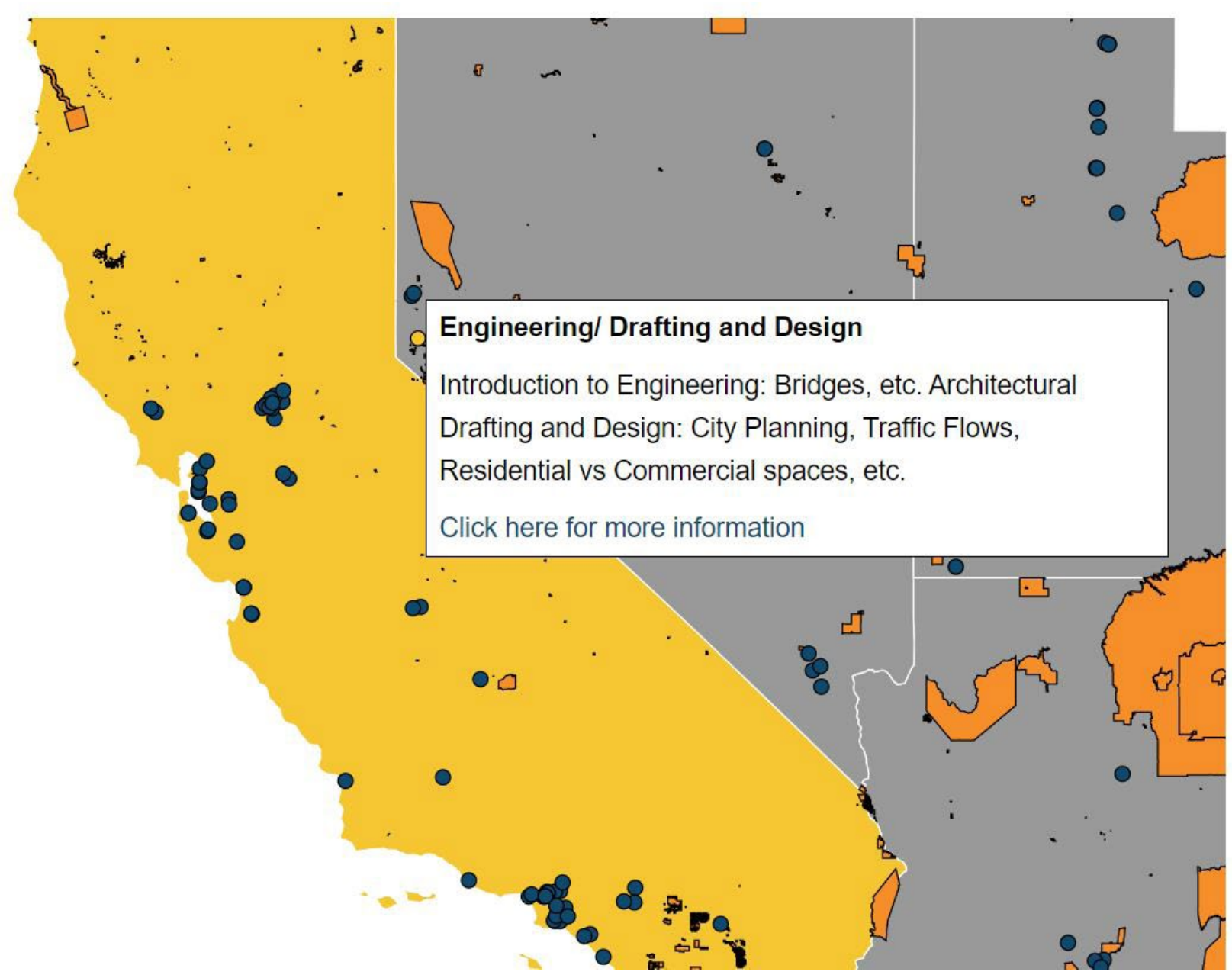

Figure 10. An Example from the Southwest Transportation Workforce Center of Visualizing the Location of Training Opportunities

This approach of building an online community will prove helpful in a broad array of cases. Consider the following scenario: southern California Transit Agency A is deploying a new electric bus from a new manufacturer. A component unique to electrical buses malfunctions the first week while the technicians are still reviewing the manual provided by the manufacturer. Transit Agency A's lead technician logs on to the SCRTTC portal and joins a forum discussion with technicians at Transit Agency B in northern California that has worked on the same issue, having deployed the same bus from the same manufacturer six months prior. The virtual discussion provides a solution for Transit Agency A. SCRTTC staff can also note cases where sufficient solutions are not achieved via the online community and, in turn, use those instances as justifications for targeted future training efforts. 
Related web-based recommendations for SCRTTC include the development of a more intuitive mobile version of the SCRTTC website. A majority of users now access websites via mobile devices rather than desktops. ${ }^{10}$ Mobile-friendly interfaces are particularly important for SCRTTC's technician user base, which typically lacks desktop computer access and organizational email account. Through careful coordination and verification with SCRTTC members, the consortium could develop new ways to empower technicians to access training resources and participate in a digitally engaged transit technician community of practice. Such a community would help SCRTTC move beyond the limits of surveys and other assessment methods to gain more real-time insights about technician training needs.

Implementing the enhanced digital platform recommended in this report would send a clear signal to SCRTTC members and its technician user base that increased accessibility to training resources is a top priority. That platform would enable the creation of an online community for SCRTTC members-further instantiating a consortium policy practice devoted to accessibility and responsiveness. Such a community would establish SCRTTC as a national model for convening the transit technician workforce through online and targeted in-class training offerings. In that context, technicians would populate the forum with the latest problems and solutions in transit. SCRTTC would then use that information and user data, on an ongoing basis, to analyze trends and identify training priorities to empower the transit maintenance workforce. 


\section{CONCLUSION}

California's Senate Bill 1 (SB-1), a law passed in 2017 to allocate funding for transportation improvements, dedicates funds specifically for state university research. This grant money is intended to fund "transportation research and transportation-related workforce education, training, and development," which are SCRTTC's core priorities. SCRTTC has demonstrated, over its 15 years of existence, a dedication to excellence in transportation workforce training and development. Reflected in the consistency of responses from survey and interview participants, SCRTTC provides quality education to incumbent workers that is both relevant to their current positions and promotes career development in the transit industry.

Despite this consistency of positive regard for the quality of coursework SCRTTC offers, there was a similar frequency attached to the sentiment that SCRTTC needed to offer more courses in more accessible and customized ways. Respondents referenced both expanding the geographic availability of courses and adding more online courses as ways to improve upon what SCRTTC already offers. As previously discussed, moving to a statewide CTTC (California Transit Training Consortium) model could be a step in a direction that the consortium is already taking, with its presence in Fresno and San Francisco already established. Yet expansion can have financial implications and finding funding to support such an expansion can create challenges. Any steps to further develop SCRTTC into a statewide model should be done carefully and with an eye for fiscal sustainability. Looking to other regional and national consortia (like the Florida Transportation Maintenance Consortium or the Transportation Learning Center, respectively) for best practices and new delivery models for training and course development from other industries could provide important guidance for this process, and further research into these and other examples would be beneficial.

Further development of SCRTTC's online presence is one area of expansion that could prove cost-effective and simultaneously address member desires for increased content. In an increasingly Web-based society, the importance of offering remote courses and easyto-use online interfaces becomes vital. Creating a mobile-friendly interface and developing online forums for technicians and managers to troubleshoot in a Web-based community would increase the relevance and perceived necessity of SCRTTC as an entity. This is another area where further research into other regional models could provide useful insights for future implementation. Looking to the online curriculum repositories available through the Transit Training Network (a subsidiary of the Transportation Learning Center) or the Northeast Transportation Workforce Center may provide guidance for implementation of that and other online recommendations suggested in this report.

In short, a fiscally conscious expansion of SCRTTC to the greater California region that incorporates increased online course offerings and website development could provide opportunities for SCRTTC to better meet the needs of incumbent and future technician and continue to progress towards its goal of providing cutting-edge and highly relevant training and workforce development. 


\section{APPENDIX: SCRTTC COURSE CATALOG}

\section{Track 1}

D1-DVOM/ITS Tech SC-DV-2700-I

E1-Electric I for Transit SC-EL-1600-I

\section{Track 2 (General)}

B1-Brakes I for Transit SC-BR-1300-I

B2-Brakes II for Transit SC-BR-1300-II

E2-Electrical II for Transit SC-EL-1600-II

E3-Electrical III for Transit SC-EL-1600-III

E4-Electrical IV for Transit SC-EL-1600-IV

E5-Electrical V for Transit SC-EL-1600-V

EG1-Engines 8.3 C+ Basic SC-EN-1700-I

EG2-Engines 8.3 C+ Adv SC-EN-1701-I

EG3-Engines 8.9 Basic - Level I - SC-EN-1710-I

EG4 Engines 8.9 Advanced - Level II SC-EN-1711-I

EG5 Engines Cummins Insite SC-EN-1712-I

Track 3 (Advanced)

H1-HVAC I SC-HV-3000-I

H2-HVAC II SC-HV-3000-II

HY1 Hybrid Safety \& Familiarization SC-HY-4000-I

HY2 Hybrid Advanced Familiarization \& Operations SC-HY-4010-I

HY3 Hybrid PM SC-HY-4020-I

HY4 Hybrid Advanced Diagnostics SC-HY-4030-I

HY5 Hybrid Ford Engine Operations SC-HY-4040-I 


\section{Track 4 (Vehicle/Special)}

CNG Transit Vehicle Safety SC-CG-4100-I

CNG Transit Vehicle Safety Training - SC-CG-4111-X

Leadership-Transition to Supervisor SC-LD-8800-I

Leadership In-class/Distance Learning SC-eLD-8801-DE-I

OSHA Basic Safety Course SC-OS-9999-I

Introduction and Troubleshooting Zero Emission Propulsion (ZEPS) SC-ZE-4400-1

EV Transit Bus Safety Awareness and Familiarization SC-BEV-5000-I

\section{Track 5 (Distance Based Technical Courses)}

eDigital Volt-Ohm Meter (DVOM) and ITS SC-eDV-2700-DE-I

TM

eCummins INSITE Diagnostic Software SC-eEN-1712-DE-I

eElectrical System Diagnosis for Transit SC-eEL-1600-DE-I

eCNG Transit Vehicle Safety SC-eCG-4100-DE-I

Introduction to HVAC for Transit-Blended Course SC-eHV-3000-DE-I

eEV Transit Bus Safety Awareness and Familiarization SC-eBEV-5000-DE-I 


\section{ABBREVIATIONS AND ACRONYMS}

\begin{tabular}{ll}
\hline ASE & Automotive Service Excellence \\
BLS & Bureau of Labor Statistics \\
CITT & Center for International Trade and Transportation \\
CNG & Compressed natural gas \\
CSULB & California State University, Long Beach \\
CRM & Customer relationship management \\
IDI & In-depth interviews \\
IRB & Institutional Review Board \\
IT & Information technology \\
ITS & Intelligent transportation systems \\
NNTW & National Network for the Transportation Workforce \\
OEM & Original equipment manufacturer \\
SCRTTC & Southern California Regional Transit Training Consortium \\
SOC & Standard occupational codes \\
TNC & Transportation network company \\
ZEB & Zero-emission bus \\
\hline
\end{tabular}




\section{ENDNOTES}

1. "2016 Transit Workforce Training Needs Assessment," Southern California Regional Transit Training Consortium, May 16, 2016, http://scrttc.com/images/stories/PDFs/ assessments/2016_transit_train_needs_assess_final.pdf.

2. Tyler Reeb, ed., Empowering the New Mobility Workforce: Educating, Training, and Inspiring Future Transportation Professionals (Cambridge: Elsevier, 2019).

3. Tyler Reeb, ed., Empowering the New Mobility Workforce: Educating, Training, and Inspiring Future Transportation Professionals (Cambridge: Elsevier, 2019).

4. "Southern California Regional Transit Training Consortium Course Catalog," Southern California Regional Transit Training Consortium, https://www.scrttc.com/images/stories/ PDFs/brochure-scrttc.pdf.

5. "Southern California Regional Transit Training Consortium Course Catalog," Southern California Regional Transit Training Consortium, https://www.scrttc.com/images/stories/ PDFs/brochure-scrttc.pdf.

6. Laura J. Nelson, "L.A. is hemorrhaging bus riders - worsening traffic and hurting climate goals," Los Angeles Times, June 27, 2019, https://www.latimes.com/local/lanow/la-meIn-bus-ridership-falling-los-angeles-la-metro-20190627-story.html.

7. Xiang Yan, Jonathan Levine, and Xilei Zhao, "Integrating ridesourcing services with public transit: An evaluation of traveler responses combining revealed and stated preference data," Transportation Research Part C: Emerging Technologies 105 (2019): 683-969 https://doi.org/10.1016/j.trc.2018.07.029.

8. Eric Jaffe, "How the Microtransit Movement Is Changing Urban Mobility," CityLab, April 27, 2015, https://www.citylab.com/transportation/2015/04/how-the-ban-mobility/391565/.

9. Stephen Billett, "Apprenticeship as a mode of learning and a model of education," Education + Training 58 (2016): 613-628. https://doi.org/10/1108/ET-01-2016-0001.

10. Eric Enge, Where is the Mobile vs. Desktop Story Going? (Perficient, April 11, 2019). https://www.perficientdigital.com/insights/our-research/mobile-vs-desktop-usage-study. 


\section{BIBLIOGRAPHY}

Billett, Stephen. "Apprenticeship as a mode of learning and a model of education." Education + Training 58 (2016): 613-628. https://doi.org/10/1108/ET-01-2016-0001.

Enge, Eric. Where is the Mobile vs. Desktop Story Going? Perficient, April 11, 2019. https:// www.perficientdigital.com/insights/our-research/mobile-vs-desktop-usage-study.

Jaffe, Eric. "How the Microtransit Movement Is Changing Urban Mobility." CityLab, April 27, 2015. https://www.citylab.com/transportation/2015/04/how-the-ban-mobility/391565/.

Nelson, Laura J. "L.A. is hemorrhaging bus riders - worsening traffic and hurting climate goals." Los Angeles Times, June 27, 2019. https://www.latimes.com/local/lanow/lame-In-bus-ridership-falling-los-angeles-la-metro-20190627-story.html.

Southern California Regional Transit Training Consortium. "2016 Transportation Workforce Training Needs Assessment." May 16, 2016. http://scrttc.com/images/stories/PDFs/ assessments/2016_transit_train_needs_assess_final.pdf.

Southern California Regional Transit Training Consortium. "Southern California Regional Transit Training Consortium Course Catalog." https://www.scrttc.com/images/ stories/PDFs/brochure-scrttc.pdf.

Tyler Reeb, ed., Empowering the New Mobility Workforce: Educating, Training, and Inspiring Future Transportation Professionals. Cambridge: Elsevier, 2019.

Yan, Xiang, Jonathan Levine, and Xilei Zhao. "Integrating ridesourcing services with public transit: An evaluation of traveler responses combining revealed and stated preference data." Transportation Research Part C: Emerging Technologies 105 (2019): 683-969. https://doi.org/10.1016/j.trc.2018.07.029. 


\section{ABOUT THE AUTHORS}

TYLER REEB, PH.D.

Dr. Tyler Reeb is the Director of Research and Workforce Development for CITT and the Associate Director of the Federal Highway Administration's Southwest Transportation Workforce Center housed at CITT. He also serves as the editor of METRANS NEWS, a triquarterly publication that summarizes METRANS research, education, and outreach efforts. Dr. Reeb is the editor and principal author of Empowering the New Mobility Workforce: Educating, Training, and Inspiring Future Transportation Professionals (Elsevier, 2019). Dr. Reeb leads teams of researchers who address challenges and opportunities related to the new mobility workforce, transformational technology, institutional change, organizational management, and transportation systems management operations (TSM\&O). He draws from industry benchmarking, labor market analysis, future scenario planning, systems thinking, enterprise resource planning, and GIS tools to produce research-driven reports, articles/whitepapers, books, and multimedia products that promote innovation and civic partnerships between leaders in business, government, and education. Dr. Reeb was the lead author for a successful \$1.5 million FHWA grant application to fund deployment of the National Transportation Career Pathway Initiative. He is a member of two standing committees of the National Academies of Sciences, Engineering, and Medicinefocused on Transportation Education \& Training and Native American Transportation Issues. Dr. Reeb has a Bachelor's in English Literature and Mass Media and a Ph.D. in English with an emphasis in Transdisciplinary Research Methods.

\section{BENJAMIN OLSON}

Benjamin Olson is the Research and GIS Coordinator at the Center for International Trade and Transportation (CITT) at CSULB. He received his Master's in Geographic Information Science from CSULB and his Bachelor's in Statistics and Spanish from the University of Illinois, Urbana-Champaign (UIUC). Olson started at CITT as a Research Assistant when a graduate student. As a research assistant, he and his partner were named finalists in the 2018 Southern California Association of Governments (SCAG) annual Student Showcase Story Map Challenge for their story map narrating the hypothetical transportation planner career pathway of a high school student interested in GIS. As an undergraduate, he participated in research with the UIUC Department of Statistics working with cognitive diagnosis models. Olson has also previously worked in the GIS Department at the City of Irvine and at Caterpillar Inc.'s Data Innovation Lab at UIUC. 


\section{PEER REVIEW}

San José State University, of the California State University system, and the Mineta Transportation Institute (MTI) Board of Trustees have agreed upon a peer review process required for all research published by $\mathrm{MTI}$. The purpose of the review process is to ensure that the results presented are based upon a professionally acceptable research protocol. 


\author{
Founder, Honorable \\ Norman Mineta (Ex-Officio) \\ Secretary (ret.), \\ US Department of Transportation \\ Chair, \\ Abbas Mohaddes (TE 202I) \\ President \& COO \\ Econolite Group Inc. \\ Vice Chair, \\ Will Kempton (TE 2022) \\ Retired \\ Executive Director, \\ Karen Philbrick, PhD \\ (Ex-Officio) \\ Mineta Transportation Institute \\ San José State University \\ Richard Anderson \\ (Ex-Officio) \\ President \& CEO \\ Amtrak \\ David Castagnetti (TE 202 I) \\ Co-Founder \\ Mehlman Castagnetti \\ Rosen \& Thomas \\ Maria Cino (TE 202 I) \\ Vice President \\ America \& U.S. Government \\ Relations Hewlett-Packard Enterprise
}

\author{
Grace Crunican* \\ (TE 2022) \\ Retired
}

Donna DeMartino (TE 202I)

General Manager \& CEO

San Joaquin Regional Transit District

Nuria Fernandez* (TE 2020)

General Manager \& CEO

Santa Clara Valley

Transportation Authority (VTA)

John Flaherty (TE 2020)

Senior Fellow

Silicon Valley American

Leadership Form

Rose Guilbault (TE 2020)

Board Member

Peninsula Corridor

Joint Powers Board

Ian Jefferies (Ex-Officio)

President \& CEO

Association of American Railroads

Diane Woodend Jones

(TE 2022)

Principal \& Chair of Board

Lea + Elliott, Inc.
Therese McMillan

(TE 2022)

Executive Director

Metropolitan Transportation

Commission (MTC)

Bradley Mims (TE 2020)

President \& CEO

Conference of Minority

Transportation Officials (COMTO)

Jeff Morales (TE 2022)

Managing Principal

InfraStrategies, LLC

Dan Moshavi, PhD

(Ex-Officio)

Dean, Lucas College and

Graduate School of Business

San José State University

Takayoshi Oshima (TE 202 I)

Chairman \& CEO

Allied Telesis, Inc.

Toks Omishakin

(Ex-Officio)

Director

California Department of

Transportation (Caltrans)
Paul Skoutelas (Ex-Officio)

President \& CEO

American Public Transportation

Association (APTA)

Dan Smith (TE 2020)

President

Capstone Financial Group, Inc.

Beverley Swaim-Staley (TE 2022)

President

Union Station Redevelopment

Corporation

\section{Jim Tymon (Ex-Officio)}

Executive Director

American Association of

State Highway and Transportation

Officials (AASHTO)

\section{Larry Willis (Ex-Officio)}

President

Transportation Trades

Dept., AFL-CIO

$(\mathrm{TE})=$ Term Expiration

* = Past Chair, Board of Trustees

\section{Directors}

Karen Philbrick, Ph.D.

Executive Director

Hilary Nixon, Ph.D.

Deputy Executive Director

\section{Asha Weinstein Agrawal,}

\section{Ph.D.}

Education Director

National Transportation Finance

Center Director

\section{Brian Michael Jenkins}

National Transportation Security

Center Director

\title{
Research Associates Policy Oversight Committee
}

Jan Botha, Ph.D.

Civil \& Environmental Engineering

San José State University

Katherine Kao Cushing,

\section{Ph.D.}

Enviromental Science

San José State University

Dave Czerwinski, Ph.D. Marketing and Decision Science San José State University
Frances Edwards,

Ph.D.

Political Science

San José State University

Taeho Park, Ph.D.

Organization and Management

San José State University

\section{Christa Bailey}

Martin Luther King, Jr. Library

San José State University

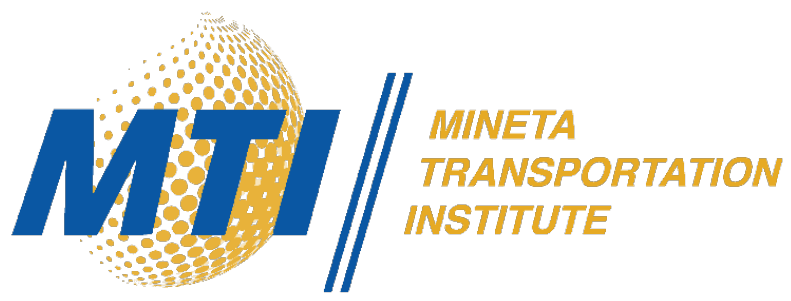

